\title{
EFEK DINAMIKA LINGKUNGAN SEBAGAI MODERASI PENGARUH INOVASI TERHADAP KINERJA KEUANGAN (STUDI EMPIRIS SEKTOR TELEKOMUNIKASI DI BURSA EFEK INDONESIA)
}

\author{
Yuliani \\ Fakultas Ekonomi Jurusan Manajemen \\ Universitas Sriwijaya
}

\begin{abstract}
This study aims to describe and analyze the direct effect of innovations on the financial performance, to measure and analyze the effects of environmental dynamics as a moderating influence innovation on the financial performance. The study was conducted in the telecommunications sector in Indonesia Stock Exchange (IDX) with the observation period 2008-2012. The sampling method is saturated. The unit of analysis of 30 cases by using Structural Equation Modeling (SEM)-based variance that is SmartPLS Ver 2.0 M3. Research findings that innovation is significant and positive effect on financial performance. Effects of environmental dynamics as a quasi moderating influence is weakening innovation on financial performance.
\end{abstract}

Keywords:

Innovations, environmental dynamics, financial performance 


\section{PENDAHULUAN}

Kondisi inovasi di Indonesia saat ini sungguh memprihatinkan, pada tahun 20122013, peringkat inovasi Indonesia, dengan penduduk hampir 250 juta jiwa, hanya menduduki urutan ke-38 dari 148 negara. Sedangkan Malaysia, dengan penduduk sekitar 27 juta jiwa, mampu menempati urutan ke-24. Konsekuensinya, indeks daya saing (Competitiveness Index) Indonesia menempati urutan ke-54 (www.feforum.org).

Upaya mendorong kegiatan inovasi, Pemerintah Indonesia membentuk Dewan Inovasi Nasional atau BIC (Business Innovation Centre) yang diharapkan dapat menjembatani institusi penelitian, pengembangan dan rekayasa (Litbangyasa) dengan industri melalui berbagai program antara lain Research and Development (R\&D) visit, industry visit, business gathering, matchmaking dan konsultasi inovasi (www.ristek.go.id). Walaupun telah dibentuk lembaga oleh pemerintah, namun inovasi yang dilakukan oleh perusahaan besar masih relatif rendah. Sumber pembiayaan penelitian dan pengembangan (Litbang), sebagian besar (>70\%) masih berasal dari anggaran pemerintah dan pelaksana litbang-pun hampir semuanya merupakan merupakan institusi pemerintah. Hal ini berbeda dengan negara-negara maju,

dimana belanja litbang sebagian besar berasal dari dunia usaha/industri dan pelaksana litbang juga banyak dari dunia usaha, belum mampu memberikan kontribusi yang signifikan terhadap pembangunan perekonomian nasional (Renstra Kementerian Riset dan Teknologi, 2010).

Padahal inovasi sangat penting dalam menciptakan daya saing. Daya saing ekonomi suatu negara ditentukan oleh kreativitas sumber daya manusia (Solanas, 2008:162). Daya saing tersebut berakar dari inovasi. Inovasi merupakan kegiatan pengembangan dan penggunaan gagasan baru atau perilaku dalam organisasi. Bentuk inovasi dalam perusahaan bisa berupa produk, jasa, metode produksi, pasar, struktur organisasi atau sistem administrasi baru (Damanpour \& Wichnevsky, 2006). Dengan demikian, inovasi sangat penting bagi pertumbuhan dan sistem ekonomi (Solow, 1959; Romer, 1990; Aghion \& Howitt, 1992).

Salah satu indikator inovasi yang dilakukan perusahaan tampak pada besarnya biaya R\&D dan biaya lain yang terkait seperti biaya tenaga ahli, jasa profesional, jasa konsultan. Besarnya biaya R\&D, perkembangan $\mathrm{R} \& \mathrm{D}$ dan proporsinya terhadap total aktiva untuk perusahaan sektor telekomunikasi yang tercatat di BEI tampak pada Tabel 1.

Tabel 1.

Jumlah Biaya R\&D, Perkembangan dan Proporsinya terhadap

Total Aktiva Perusahaan Telekomunikasi (2008-2012)

\begin{tabular}{|c||c||c||c||c||}
\hline \hline Tahun & $\begin{array}{c}\text { Jumlah Biaya terkait } \\
\text { dengan R\&D (Rp Juta) }\end{array}$ & $\begin{array}{c}\text { Perkembangan } \\
(\%)\end{array}$ & $\begin{array}{c}\text { Total Aktiva (Rp } \\
\text { Juta) }\end{array}$ & $\begin{array}{c}\text { Proporsi R\&D terhadap } \\
\text { Total Aktiva (\%) }\end{array}$ \\
\hline \hline 2008 & 427.192 & - & 186.082 .551 & 0,230 \\
\hline \hline 2009 & 478.458 & 0,120 & 200.322 .383 & 0,239 \\
\hline \hline 2010 & 483.729 & 0,011 & 204.360 .723 & 0,237 \\
\hline \hline 2011 & 584.726 & 0,209 & 224.652 .415 & 0,260 \\
\hline \hline 2012 & 668.864 & 0,144 & 147.702 .436 & 0,453 \\
\hline
\end{tabular}

Sumber : Data diolah 
Tabel 1. diatas tampak bahwa biaya R\&D selama lima tahun menujukkan perkembangan yang cukup lambat dengan kecenderungan relatif tidak stabil. Perkembangan relatif baik terjadi pada tahun 2011 yakni sebesar 20,9\% perusahaan sektor telekomunikasi mengeluarkan dana untuk R\&D, tahun sebelumnya yakni 2010 perkembangan sangat lambat 0,011 atau $1,1 \%$ walaupun secara total terjadi peningkatan terhadap biaya $R \& D$ namun perkembangan dari tahun ke tahun relatif lambat. Sedangkan proporsi biaya R\&D terhadap total aktiva relatif baik yakni hampir mendekati 0,25 atau 25\% bahkan di tahun 2012 sektor telekomunikasi memberikan porsi yang relatif besar terhadap jumlah total aktiva sebesar 45,3\%. Merujuk pada perkembangan biaya $R \& D$ yang relatif lambat menunjukkan bahwa sektor telekomunikasi yang terdaftar di BEI ada kecenderungan bahwa kurangnya kesadaran pentingnya daya saing bagi perusahaan, sehingga para investor kurang tertarik untuk berinvestasi pada sektor ini, hal ini dapat diamati bahwa relatif jarang sektor ini menjadi pendongkrak dalam peningkatan Indeks Harga Saham Gabungan (IHSG).

Sektor telekomunikasi merupakan perusahaan-perusahaan yang bergerak pada industri yang memberikan pertukaran informasi untuk hubungan yang relatif dikategorikan sebagai hubungan jarak jauh. Perjalanan industri telekomunikasi di Indonesia saat ini dimulai dari kehadiran Undang-Undang No.36/1999 tentang telekomunikasi merupakan awal yang baik bagi kompetisi pasar telekomunikasi di Indonesia. Perusahaan sektor telekomunikasi yang terdaftar di BEI saat ini berdasarkan Indonesian Capital Market Directory (ICMD, 2012) sebanyak sembilan emiten yaitu Telekomunikasi Indonesia (Persero), Indosat, XL Axiata, Smartfren Telecom, Tower Bersama Infrastruktur, Trikomsel
Oke, Inovisi Infracom dan Renewable Power Indonesia/Katarina Utama.

Penelusuran kajian terdahulu tentang pengaruh besarnya inovasi terhadap kinerja keuangan perusahaan menghasilkan temuan yang hampir sejalan dengan prediksi teoritik. Dimana hasil temuan yang tersebut semua dilakukan di negara maju seperti (Hall, 1993; Srinivasan et al., 2008; Sorescu \& Spanjol, 2008). Sedangkan penelitian yang menggunakan objek penelitian Pasar Modal Indonesia yakni BEI relatif masih jarang dilakukan. Peranan inovasi sering diabaikan dalam penelitian manajemen keuangan khususnya untuk kajian empiris di Indonesia. Berdasarkan alasan ini, maka motivasi penulis untuk melakukan kajian ini dengan mengoperasionalkan variabel moderasi yaitu dinamika lingkungan.

Alasan memasukkan dinamika lingkungan sebagai moderasi pengaruh inovasi terhadap kinerja keuangan dengan alur pemikiran penulis bahwa setiap keputusan terkait dengan jumlah biaya $R \& D$ yang akan dikeluarkan, perusahaan perlu melihat kondisi lingkungan internal dan eksternal. Lingkungan internal berkaitan dengan keseluruhan kondisi yang berasal dari perusahaan yang meliputi sumber daya, kapabilitas dan kompetensi inti yang dimiliki perusahaan, sedangkan lingkungan eksternal adalah lingkungan umum, industri dan lingkungan pesaing (Hitt et al., 2011:16). Sedangkan Wheelen \& Hunger (2000:10) menguraikan lingkungan industri merupakan bagian dari lingkungan bisnis eksternal yang dapat memengaruhi pencapaian kinerja selain lingkungan makro. Lingkungan makro terdiri dari faktor ekonomi, ekologi, hukum, politik, sosial budaya dan teknologi, sedangkan lingkungan internal terdiri dari struktur organisasi, budaya organisasi dan sumber daya.

Selanjutnya uraian lingkungan juga dijelaskan oleh Pearce \& Robinson 
(2011:72) menyatakan bahwa lingkungan bisnis eksternal memengaruhi organisasi terdiri dari lingkungan makro dan lingkungan industri. Lingkungan industri juga berperan dalam mempercepat perubahan lingkungan. Lingkungan industri yang dimaksud adalah bargaining power pembeli, bargaining power pemasok, masuknya pendatang baru yang potensial, adanya barang substitusi dan persaingan perusahaan yang sudah ada dalam industri.

Hasil penelitian yang ada juga menunjukkan bahwa lingkungan dapat memengaruhi kinerja perusahaan (Keats \& Hitt, 1988). Bahkan penelitian Mc Arthur \& Nystrom (1991) memfokuskan pada studi yang berhubungan dengan tiga dimensi lingkungan yaitu lingkungan yang bersifat dinamis, lingkungan yang bersifat kompleks dan lingkungan yang bersifat liberal. Lingkungan yang bersifat dinamis digambarkan dalam beberapa wujud. Seperti Mintzberg (1979) merefleksikan dengan ketidakstabilan atau turbulensi atau gejolak pasar yang terjadi sepanjang waktu yang disebabkan karena interkoneksi atau hubungan antar organisasi atau perusahaan. Sedangkan Hambrick mengoperasionalisasikan lingkungan dinamis sebagai inovasi produk terbaru yang memperlihatkan pengaruh utama terhadap pengukuran kinerja.

Penelitian lain yaitu Li \& Simerly (1998) di sektor food and beverage industry dan sektor computer and electronic industry pada tahun 1994 di Amerika, memasukkan lingkungan dinamis sebagai variabel moderasi antara kepemilikan dan kinerja perusahaan. Hasilnya menyatakan bahwa secara jelas increased insider ownership akan menghasilkan tingkat keuntungan yang signifikan dibawah kondisi lingkungan dinamis. Hasil penelitian ini dapat dimaknai bahwa pemoderasi lingkungan dinamis akan memperkuat hubungan kepemilikan terhadap peningkatan kinerja perusahaan.

Berdasarkan uraian diatas, maka permasalahan penelitian ini meliputi: 1) apakah inovasi secara langsung berpengaruh signifikan terhadap kinerja keuangan? 2) apakah dinamika lingkungan signifikan memoderasi pengaruh inovasi terhadap kinerja keuangan?. Tujuan penelitian ini adalah 1) menjelaskan dan menganalisis pengaruh langsung inovasi terhadap kinerja keuangan, 2) mengukur dan menganalisis peran dinamika lingkungan sebagai moderasi pengaruh inovasi terhadap kinerja keuangan.

\section{TINJAUAN PUSTAKA}

\subsection{Inovasi}

Inovasi sebagai suatu aktivitas merupakan semua aktivitas keilmuan, keteknologian, keorganisasin, keuangan dan komersialisasi termasuk investasi dalam knowledge baru (OECD, 2005). Inovasi dikaji dalam berbagai disiplin ilmu dan telah didefinisikan dalam berbagai perspektif (Sujono, 2010). Beberapa perspektif tersebut yaitu inovasi menurut Schumpeter (1934); perspektif Teori Organisasi Industrial, perspektif inovasi organisasional, perspektif Teori Marketing, perspektif para sosiologi, perspektif evolusioner dan sistem dan perspektif menurut Resources Based Value (RBV).

Berbagai perspektif tentang inovasi dari berbagai disiplin ilmu memunculkan satu kata kunci yaitu kebaruan atau novelti (newness/novelty). Suatu inovasi dikatakan baru bagi adopter individual, bagi sebagian besar unit adopsi, bagi organisasi secara keseluruhan, bagi seluruh organisasi dalam populasi organisasi atau bagi seluruh dunia. Tingkat kebaruan dapat digunakan untuk membedakan generation innovation dari adoption innovation. 
Suatu generation innovation dalam menghasilkan outcome-product, service atau teknologi minimal baru bagi populasi organisasi-organisasi yang mengadopsi inovasi ini. Inovasi yang demikian bisa diperoleh daripihak lain atu membuat imitasinya. Setiap adopsi pada dasarnya suatu inovasi yang dibuat di tempat lain, tidak ada adopsi inovasi dilakukan dalam organisasi yang mengadopsi inovasi tersebut (Angle \& Van de Ven, 2000). Adopsi inovasi dihasilkan dalam asimilsasi produk, jasa atau teknologi baru bagi adopting organization. Penelitan tentang inovasi dalam suatu organisasi sering dibedakan antara generating process dan adopting process, dan keduanya sebagai inovasi proses.

Generating inovasi diharapkan berkontribusi terhadap efektivitas organisasi dan competitiveness melalui penciptaan peluang baru atau dengan menggunakan peluang yang ada dalam cara yang baru (Drucker, 1985). Beberapa penulis mendefenisikan center innovation untuk sebagai istilah generation of innovation (Roberts, 1988 dan Afuah, 2003). Kedua penulis tersebut menyimpulkan bahwa inovasi sebagai the development of an idea or invention and its conversion to a useful application (pengembangan gagasan atau invention dan mengkonversinya untuk aplikasi yang berguna). Inovasi adalah invention plus exploitation. Invention process menciptakan new idea dan apabila sudah diperoleh maka akan digunakan sendiri dalam organisasinya. Ekploitasi proses mengembangkan dan menyebarkan komersialisasi inovasi (Robert, 1988). Innovation-generating organizaiton merupakan kegiatan terkait dengan pengenalan produk, service, teknologi yang baru bagi pasar (Hitt et al, 1997).

Adoption of innovating diharapkan dapat berkontribusi pada efektiveness dan compentitiveness organisasi melalui adopting organizational sehingga dapat mengadopsi kondisi baru dan lingkungan eksternalnya. Organisasional berubah dengan memperkenalkan perilaku yang berbeda dari perilaku yang ada saat ini. Perubahan terjadi ketika organisasi berevolusi dari perilaku dan metode operasi lama ke metode yang baru. Perubahan tersebut adalah pergeseran atau transfer dari kondisi saat ini menuju suatu kondisi dimasa yang akan datang setelah perubahan (Nadler \& Tushman, 1997). Perbedaan antara current and future state organization dapat berkonsekuensi terhadap adopsi inovasi.

Inovasi mencakup semua aktivitas dalam usaha menciptakan produk dan proses baru termasuk inovasi marketing dan keorganisasian. Namun, jantung dari inovasi yang melahirkan produk, pasar, metode yang memiliki ciri kebaruan, dilahirkan melalui R\&D, baik dibentuk secara formal (lazim dilakukan di perusahaan skala besar) maupun tidak. Untuk melindungi temuan produk atau proses baru perusahaan mendaftarkan temuannya ke suatu badan atau lembaga tertentu yang berwenang untuk mengeluarkan paten. Jadi paten merupakan bentuk output intermediate inovasi agar terlindung dari pemalsuan.

\subsection{Dinamika Lingkungan}

\subsubsection{Pengertian Lingkungan Eksternal}

Perusahaan dapat memperoleh informasi yang dibutuhkan untuk mengerti kondisi saat ini serta memprediksi masa yang akan datang sehingga integrasi antar lingkungan harus menjadi perhatian. Pengklasifikasian lingkungan terdiri dari internal dan eksternal. Lingkungan eksternal terdiri dari dua komponen utama yaitu lingkungan umum dan lingkungan industri (David, 2003:39).

Lingkungan umum (general environment) mencakup elemen dalam masyarakat luas yang dapat memengaruhi 
suatu industri dan perusahaan-perusahaan didalamnya. Elemen-elemen ini dikelompokkan ke dalam segmen lingkungan (environment segments), yang terdiri dari segmen-segmen demografi, ekonomi, politik/hukum, fisik, sosial budaya, global serta teknologi. Perusahaan tidak dapat mengendalikan elemen-elemen ini secara langsung. Karenanya, tantangan strategisnya adalah untuk mengerti setiap segmen dan implikasi masing-masing, sehingga strategi yang tepat dapat dirumuskan dan diterapkan.

Lingkungan industri (industry environment) merupakan sekelompok faktor ancaman masuknya pendatang baru, pemasok, pembeli, produk pengganti dan intensitas persaingan antarpesaing yang memengaruhi suatu perusahaan. Secara keseluruhan interaksi antar kelima faktor ini menentukan posisi dalam industri di mana perusahaan dapat memengaruhi faktor-faktor tersebut dengan baik, atau dengan baik pula dapat mempertahankan diri dari pengaruh faktor-faktor diatas. Semakin besar kapasitas perusahaan untuk memengaruhi lingkungan industrinya, akan semakin besar pula kecenderungan perolehan laba diatas ratarata. Analisis pesaing adalah prediksi mengenai dinamika langkah, tanggapan dan maksud para pesaing. Secara keseluruhan kinerja perusahaan akan meningkat jika perusahaan mengintegrasikan hasil analisis lingkungan umum, lingkungan industri dan pesaing. Fokus dalam penelitian ini adalah lingkungan industri dimana sebagai tantangan bagi perusahaan adalah untuk menentukan posisi dalam industri di mana perusahaan berada. Posisi dalam industri berarti perusahaan akan melihat struktur pasar.

Analisis lingkungan industri jauh lebih penting dan lebih menentukan aturan persaingan dibandingkan dengan analisis lingkungan umum. Dapat diilustrasikan bahwa jika terjadi perubahan lingkungan umum, misalnya terhadap perubahan segmen-segmen demografi, ekonomi, politik/hukum, fisik, sosial budaya, global serta teknologi maka yang kena pengaruh akibat perubahan-perubahan tersebut adalah semua perusahaan yang ada dalam suatu industri. Oleh sebab itu, jika terjadi perubahan pada tingkatan lingkungan umum kunci keberhasilan terletak pada kemampuan yang berlainan dari masingmasing perusahaan untuk menanggulangi implikasi dari perubahan tersebut.

\subsubsection{Tujuan Analisis Lingkungan Eksternal}

Analisis lingkungan eksternal bertujuan untuk mengetahui ancaman dan peluang. Ancaman merupakan suatu kondisi dalam lingkungan umum yang dapat menghambat usaha-usaha perusahaan untuk mencapai daya saing strategis. Sedangkan peluang adalah kondisi dalam lingkungan umum yang dapat membantu perusahaah mencapai daya saing strategis. Menurut Hitt et al., (2011: 42) proses yang dilakukan secara kontinyu untuk melakukan analisis lingkungan eksternal adalah dengan melakukan pemindaian (scanning), pengawasan (monitoring), peramalan (forecasting) dan penilaian (assesing). Melalui scanning perusahaan akan mempelajari seluruh segmen dalam lingkungan umum, pada proses ini perusahaan mengidentifikasi sinyal-sinyal awal perubahan yang mungkin terjadi dalam lingkungan umum dan mendeteksi setiap perubahan yang sedang terjadi. Dengan scanning, analisis secara langsung berhubungan dengan informasi dan data yang tidak jelas, tidak lengkap dan tidak berkaitan satu sama lain.

Proses monitoring, perusahaan mengamati perubahan lingkungan untuk melihat apakah suatu kecenderungan sedang berkembang. Pada tahap ini, dituntut 
kemampuan perusahaan untuk dapat mendeteksi arti dari setiap kejadian lingkungan sehingga dapat ditentukan gambaran kecenderungan tetang hal tertentu. Untuk mengetahui kecenderungan yang terjadi maka perusahaan mempelajari data atau informasi lainnya yang relevan dengan perubahan lingkungan. Monitoring terkait dengan apa yang terjadi dalam lingkungan umum pada suatu waktu tertentu. Sehingga kondisi lingkungan pada waktu tertentu akan berbeda dengan kondisi lingkungan pada waktu lainnya.

Selanjutnya proses forecasting, perusahaan melakukan prediksi tentang apa yang akan terjadi, dan seberapa cepat kecenderungan yang dideteksi melalui scanning dan monitoring. Proyeksi yang dilakukan sebagai hasil antisipasi yang memasukkan faktor-faktor lainnya dianggap konstan. Sehingga proses proyeksi harus berdasarkan data dan informasi yang diperoleh dari dua proses analisa sebelumnya. Selanjutnya proses assesing, merupakan penilaian atas proyeksi yang telah dilakukan untuk pengaruh perubahan lingkungan serta kecenderungan manajemen strategis dalam suatu perusahaan. Tujuan assestment adalah untuk menentukan implikasi terhadap perusahaan.

Beberapa

peneliti mengklasifikasikan lingkungan dengan cara yang berbeda. Balakrishnan \& Wernerfelt (1986) mengklasifikasikan lingkungan dengan environment uncertainty yang diukur dengan dua indikator yaitu volatility dan diversity dan kedua indikator ini berpengaruh kuat terhadap proses keputusan organisasi. Sedangkan Keats \& Hitt (1988), Dess \& Beard (1984) mengklasifikasikan lingkungan atas tiga indikator yaitu munificence, instability (dynamism) dan complexity. Selanjutnya penelitian ini menggunakan dua indikator sebagai refleksi karakteristik lingkungan yaitu munificence dan complexity yang merupakan karakteristik yang berbeda dalam sumber penciptaan nilai perusahaan.

Istilah munificence digunakan untuk menggambarkan hal-hal yang berhubungan dengan ketersediaan sumber daya sebagai kapasitas untuk mendukung pertumbuhan (Dess \& Beard, 1984; Keats \& Hitt, 1988). Ketersediaan sumber daya yang ada diartikan bahwa perusahaan tidak mengalami hambatan dalam hal sumber daya baik sumber daya manusia mapun sumber daya keuangan. Karakteristik munificence sebagai pertumbuhan dari lingkungan yang bersifat makro dan lingkungan industri. Munificence dapat dilihat dari pertumbuhan industri dan intensitas perubahan industri. Intensitas suatu industri dapat diukur dengan industry life cycle. Robinson \& Mcdougall (2001) menunjukkan, tahapan industry life cycle memoderasi hubungan antara rintangan masuk dan profitability. Karakteristik perilaku industri pada setiap tahapan industry life cyle berbeda yang meliputi aspek pertumbuhan, luas pasar, persaingan dan tingkat keuntungan.

Complexity didefinisikan sebagai heterogenitas dan konsentrasi terhadap elemen-elemen lingkungan (Keats \& Hitt, 1988). Kompleksitas lingkungan dapat dilihat dari struktur pasar suatu industri (Dess \& Beard, 1984). Untuk mengukur kompleksitas lingkungan beberapa peneliti menggunakan indeks konsentrasi dalam suatu industri. Robins \& Wiersema (2003) menggunakan indeks konsentrasi untuk mengukur kompleksitas lingkungan. Semakin rendah indeks konsentrasi, akan semakin kompleks lingkungan bisnis. Sebaliknya semakin tinggi indeks konsentrasi maka akan semakin tidak kompleks lingkungan industri.

\subsection{Kinerja Keuangan}

Kinerja merupakan suatu konsep dasar yang bersifat umum. Konsep ini 
biasanya dipahami secara implisit sehingga sulit untuk diungkapkan secara eksplisit. Kinerja yang terkait dengan konsep tertentu melahirkan pendekatan atau pengukuran khusus (Chakravarthy, 1986). Menurut Knipes (1988) dalam Suta (2006) mendefenisikan kata performance sebagai kinerja. Kinerja juga diartikan sebagai catatan outcome yang dihasilkan dari fungsi suatu pekerjaan atau kegiatan tertentu selama suatu periode tertentu. Hal ini sangat penting agar sumber daya digunakan secara optimal dalam menghadapi perubahan lingkungan.

Upaya untuk mencapai kinerja yang lebih baik, manajemen harus memaksimalkan kekuatan yang ada dan memperbaiki kelemah yang dimiliki. Analisis laporan keuangan menjadi sangat penting dilakukan dengan membandingkan kinerja perusahaan dengan perusahaan lain dalam industri yang sama. Hal ini dikarenakan akan membantu manajemen untuk memahami kekurangannya, daripada mengambil langsung untuk meningkatkan kinerja (Weston \& Copeland, 1995:33).

Kinerja keuangan merupakan hasil dari semua keputusan manajemen yang dilakukan secara terus-menerus. Untuk menilai kinerja perusahaan maka perlu dikaitkan dengan kinerja keuangan kumulatif dan ekonomi dari keputusan-keputusan tersebut. Analisis kinerja keuangan ini didasarkan pada data keuangan yang dipublikasikan, seperti tercermin di laporan keuangan yang dibuat sesuai dengan prinsipprinsip akuntansi yang lazim digunakan (Helfert, 2000:52). Menurut Bartol \& Martil (1994:17) menjelaskan bahwa kinerja yang telah dicapai melalui pelaksanaan dari fungsi-fungsi manajemen harus terdiri dari dua dimensi pengukuran yaitu: 1) Efektivitas, menilai apakah suatu aktivitas telah menghasilkan output yang ditargetkan, 2) Efisiensi, menilai berapa tingkat input yang dibutuhkan untuk memproduksi suatu output tertentu. Suatu aktivitas yang dapat menerapkan efektivitas dan efisiensi secara otomatis akan memenuhi target yang diinginkan. Efisiensi berhubungan dengan sumber yang digunakan, sedangkan efektivitas berhubungan dengan hasil yang dicapai.

\subsection{Kerangka Konseptual dan Hipotesis Penelitian}

Inovasi menjadi sangat penting bagi perusahaan dalam menciptakan daya saing dalam upaya meningkatkan kinerja perusahaan. Bentuk inovasi dalam perusahaan dapat berupa produk, jasa, metode produksi, pasar, struktur organisasi atau sesuatu yang menjadi kebaruan dalam proses produksi. Pada akhirnya inovasi adalah sebuah keputusan yang terkait dengan sejumlah dana yang harus dikeluarkan perusahaan. Inovasi dalam perusahaan lahir dari jumlah besarnya biaya $R \& D$ dan biaya lain seperti biaya tenaga ahli, jasa profesional, jasa konsultan yang tampak pada laporan keuangan. Usaha untuk mengembangkan dan daya saing perusahaan, maka inovasi menjadi pilihan yang tak terbantahkan. Sehingga kegiatan inovasi diharapkan akan mampu meningkatkan kinerja keuangan, artinya memberikan sinyal positif untuk para investor dan calon investor.

Beberapa studi empirik tentang pengaruh inovasi terhadap kinerja keuangan sudah banyak dilakukan untuk objek pada pasar modal yang tergolong develop market. Seperti penelitian (Hall, 1993; Srinivasan et al., 2008; Sorescu \& Spanjol, 2008) menyimpulkan bahwa kegiatan inovasi berpengaruh signifikan terhadap peningkatan kinerja perusahaan. Untuk objek pasar modal emerging market seperti di Indonesia telah dilakukan oleh Sujono (2010) menyimpulkan arah koefisien yang berbeda. Dimana hasil penelitian Sujono (2010) menggunakan 
sektor manufaktur ditemukan arah koefisien negatif artinya semakin tinggi inovasi dapat menurunkan kinerja perusahaan.

Kegiatan inovasi yang dilakukan perusahaan sektor telekomunikasi, hal penting yang perlu mendapatkan perhatian adalah faktor lingkungan industri dimana perusahaan tersebut mampu bersaing dengan perusahaan lain dalam industri yang sama. Lingkungan industri merupakan bagian dari lingkungan bisnis eksternal yang dapat memengaruhi pencapaian kinerja suatu perusahaan selain lingkungan makro. Lingkungan industri yang dimaksud adalah sekelompok faktor ancaman masuknya pendatang baru, pemasok, pembeli, produk pengganti dan intensitas persaingan antarpesaing (Hitt et al., 2011: 37). Perusahaan hendaknya selalu berusaha untuk mengamati dan menganalisis lingkungannya sehingga mampu menentukan peluang, ancaman, kekuatan dan kelemahan. Bahkan Hoskisson \& Hitt (1990) menyatakan bahwa lingkungan merupakan variabel penting untuk menguji hubungan antara strategi dan kinerja. Selanjutnya Keats \& Hitt (1988), Dess \& Beard (1984) membagi lingkungan atas tiga karateristik yaitu munificence, instability (dynamism) dan complexity. Sedangkan Balakrishnan \& Wernerfelt (1986) membagi lingkungan dengan environment uncertainty yang diukur dengan volatility dan diversity. Penelitian ini menggunakan variabel lingkungan yang diukur dengan indikator munificence dan complexity. Berdasarkan teori dan penelitian empiris yang telah dilakukan maka model hipotesis penelitian tampak pada Gambar 1.

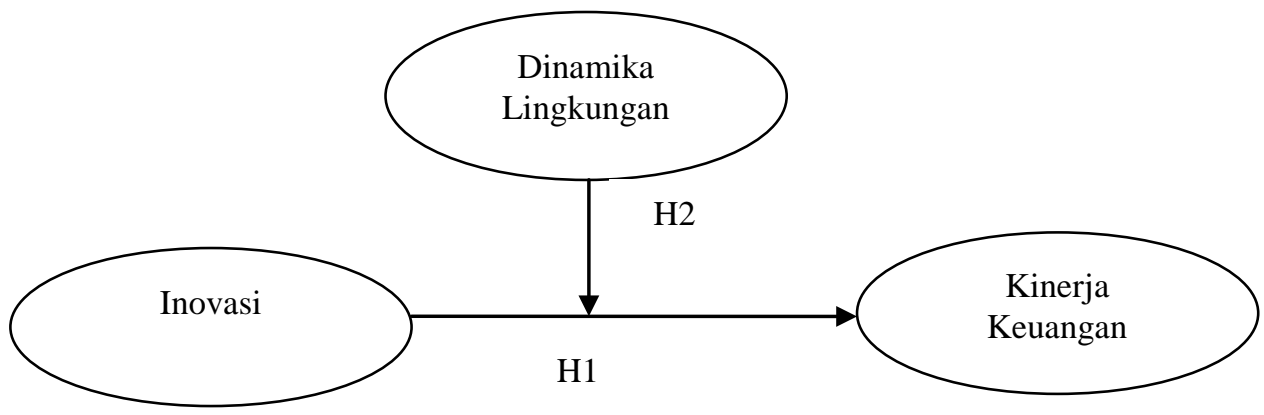

Gambar 1.

Model Hipotesis Penelitan

\subsection{Hipotesis Penelitian}

Perkembangan teknologi adalah jantung pertumbuhan ekonomi dan investasi dalam inovasi sebagai penggerak utamanya (Scherer, 1999). Peningkatan inovasi yang dilakukan perusahaan dapat meningkatkan kinerja keuangan. Penelitian terdahulu menemukan bahwa inovasi berpengaruh positif terhadap kinerja perusahaan di pasar modal yang tergolong developed (Hall, 1993; Srinivasan et al., 2008; Sorescu \& Spanjol, 2008). Sedangkan di Indonesia dengan emerging market diharapkan memiliki kesadaran pentingnya daya saing bagi perusahaan, sehingga diharapkan investor bereaksi positif terhadap kegiatan inovasi sehingga peningkatan inovasi dapat meningkatkan kinerja perusahaan. Berdasarkan uraian ini maka hipotesis yang dirumuskan adalah:

H1 : Inovasi secara langsung berpengaruh signifikan terhadap kinerja keuangan 
Kegiatan inovasi akan memperhatikan faktor lingkungan industri agar diperoleh hasil yang optimal. Maka perlu bagi perusahaan untuk melihat kondisi pesaing sehingga kegiatan inovasi dapat memperkuat peningkatan kinerja keuangan. Penelitian empirik mengenai faktor moderasi dinamika lingkungan dapat ditelusuri dari penelitian $\mathrm{Li}$ \& Simerly (1998) yang memoderasi kepemilikan terhadap kinerja perusahaan. Hasil penelitian ini ditemukan bahwa pemoderasi dinamika lingkungan memperkuat hubungan kepemilikan terhadap peningkatan kinerja perusahaan. Berbeda dengan Yuliani (2013) bahwa dinamika lingkungan tidak menjadi pemoderasi antara Investment Opportunity Set (IOS) dan nilai perusahaan. Rumusan hipotesis yang diajukan adalah:

H2 : Dinamika lingkungan signifikan memodarasi pengaruh inovasi terhadap kinerja keuangan

\section{METODE PENELITIAN}

\subsection{Pendekatan Penelitian}

Penelitian ini menggunakan pendekatan kuantitatif dengan paradigma positivist. Pendekatan penelitian ini dilakukan dengan pemaknaan masingmasing variabel maupun hubungan antar variabel didasarkan pada pengukuran kuantitatif. Berdasarkan tujuan penelitian maka jenis penelitian ini adalah penelitian eksplanatoris (explanatory research), yakni berusaha memberikan penjelasan kausal atau hubungan antar variabel melalui pengujian hipotesis.

\subsection{Populasi dan Sampel}

Populasi penelitian ini adalah seluruh perusahaan sektor telekomunikasi terdaftar di Bursa Efek Indonesia dari tahun 2008-2012 yaitu berjumlah sembilan perusahaan. Sampel ditentukan berdasarkan kriteria populasi yaitu 1) Perusahaan tidak sedang delisting, 2) Memiliki laporan keuangan lengkap periode 31 Desember 2008- 31 Desember 2012, 3) Membukukan Net Income selama periode pengamatan. Berdasarkan kriteria populasi ini terpilih enam perusahaan (Tabel 2.) sebagai sampel penelitian, sehingga metode pengambilan sampel adalah sensus. Unit analisis adalah pooling data sebanyak 30 kasus. Metode pengumpulan data penelitian ini dengan cara mengakses internet dengan membuka website resmi Bursa Efek Indonesia yaitu http://www.idx.co.id/MainMenu/Emiten/Co mpanyProfile/SubmittedOffline, IDX Fact Book 2007-2012, Annual Report 2007-2012.

Tabel 2.

Daftar Sampel Penelitian Sektor Telekomunikasi

\begin{tabular}{|c||l|c||}
\hline No & \multicolumn{1}{|c|}{ Perusahaan } & Kode \\
\hline 01 & Telekomunikasi Indonesia (Persero) Tbk & TLKM \\
\hline \hline 02 & Indosat Tbk & ISAT \\
\hline \hline 03 & XL Axiata Tbk & EXCL \\
\hline 04 & Bakrie Telecom Tbk & BTEL \\
\hline \hline 05 & Trikomsel Oke Tbk & TRIO \\
\hline \hline 06 & Invisi Infracom Tbk \\
\hline
\end{tabular}

\subsection{Operasional Variabel Penelitian}

Penelitian ini menggunakan tiga variabel yang diteliti yaitu: inovasi, dinamika lingkungan dan kinerja keuangan. Masing-masing variabel penelitian secara operasional dapat didefinisikan pada Tabel 3. 
Tabel 3.

Definisi Operasional Variabel dan Pengukuran Variabel Penelitian

\begin{tabular}{|c|c|c|c|}
\hline Variabel & Indikator & Pengukuran & Acuan \\
\hline \multirow{2}{*}{$\begin{array}{l}\text { Inovasi }\left(\mathrm{x}_{1}\right) \text { : } \\
\text { Merupakan kegiatan R\&D terkait } \\
\text { dengan tujuan menghasilkan } \\
\text { produk yang mampu diserap pasar } \\
\text { dan sebagai bagian dalam } \\
\text { intangible asset. }\end{array}$} & $\begin{array}{l}R \& D \text { to Sales } \\
\left(\mathrm{x}_{11}\right)\end{array}$ & $\frac{\text { Total } R \& \text { D Cost }}{\text { Total Sales }}$ & \multirow{2}{*}{$\begin{array}{l}\text { Titman \& } \\
\text { Wessels (1998); } \\
\text { Sujono (2010) }\end{array}$} \\
\hline & $\begin{array}{l}R \& D \text { to Total } \\
\text { Aktiva }\left(\mathrm{x}_{12}\right)\end{array}$ & $\frac{\text { Total R \& DCost }}{\text { Total Aktiva }}$ & \\
\hline \multirow{2}{*}{$\begin{array}{l}\text { Dinamika Lingkungan }\left(\mathrm{x}_{2}\right) \text { : } \\
\text { Lingkungan industri sebagai } \\
\text { faktor-faktor dan kondisi yang } \\
\text { memengaruhi profitabilitas }\end{array}$} & Munificence $\left(\mathrm{x}_{21}\right)$ & $\frac{\text { Sales }_{t}-\text { Sales }_{t-1}}{\text { Sales }_{t}}$ & \multirow[t]{2}{*}{$\begin{array}{l}\text { Dess \& Beard } \\
\text { (1984); Keats \& } \\
\text { Hitt (1988) }\end{array}$} \\
\hline & Complexity $\left(\mathrm{x}_{21}\right)$ & $\frac{\text { Total Sales }}{\text { Total Industry Sales }}$ & \\
\hline \multirow{3}{*}{$\begin{array}{l}\text { Kinerja Keuangan (y) } \\
\text { Merupakan ukuran keberhasilan } \\
\text { perusahaan atas operasi dimasa } \\
\text { lalu dan prospek dimasa yang } \\
\text { akan datang. }\end{array}$} & $\begin{array}{l}\text { Return On } \\
\text { Average Assets } \\
\left(\mathrm{y}_{11}\right) \\
\end{array}$ & $\frac{\text { Net Income }}{\text { Average Total Assets }}$ & \multirow{3}{*}{$\begin{array}{l}\text { Pandya \& Rao } \\
\text { (1998); Carton } \\
\text { \& Hofer (2006: } \\
\text { 83-89) }\end{array}$} \\
\hline & $\begin{array}{l}\text { Return on Sales } \\
\left(\mathrm{y}_{12}\right)\end{array}$ & $\frac{\text { Net Income }}{\text { Sales }}$ & \\
\hline & $\begin{array}{l}\text { Return On } \\
\text { Average Equity } \\
\left(\mathrm{y}_{13}\right)\end{array}$ & $\begin{array}{c}\text { Net Income } \\
\text { Average Total Equity }\end{array}$ & \\
\hline
\end{tabular}

\subsection{Metode Analisis Data}

\subsubsection{Statistik Deskriptif}

Statistik deskriptif diperlukan untuk memberikan gambaran terhadap variabelvariabel yang diteliti. Bentuk deskripsi dalam penelitian ini menampilkan nilai rata, maksimum, minimum dan standar deviasi terhadap variabel penelitian.

\subsubsection{Statistik Inferensial}

Statistik inferensial dalam penelitian ini menggunakan analisis kausalitas Structural Equation Model (SEM) yang berbasis component atau variance yang terkenal dengan Partial Least Square (PLS). Alasan yang melatarbelakangi pemilihan metode analisis PLS karena: 1) Variabel yang dianalisis adalah laten, 2) Model penelitian adalah rekursif, 3) Jumlah observasi relatif kecil ( $n$ kecil).
Selanjutnya dilakukan pengujian hipotesis dengan menggunakan langkahlangkah sebagai berikut:

a. Analisis Model

- Uji asumsi linearitas, digunakan untuk mengetahui apakah model telah tepat dalam menggambarkan hubungan antar variabel yang diteliti sehingga dikategorikan ke dalam model yang baik. Input untuk pengujian linearitas adalah memasukkan variabel independen dan dependen kemudian diolah dengan SPSS menggunakan Curve Fit. Keputusan mengacu pada prinsip parsimony dikatakan linear jika tingkat signifikansi lebih kecil dari 5\% $(p<0,05)$.

- Uji outer model (measurement model), digunakan untuk mengukur indikator reflektif dan formatif. Semua indikator dalam penelitian ini adalah reflektif. Pengukuran model terhadap indikator 
reflektif didasarkan pada faktor loading. Faktor loading $>0,70$ sangat direkomendasikan, namun demikian nilai faktor loading 0,50-0,60 dianggap cukup (Solimun, 2010: 177).

b. Pemeriksaan Goodness of Fit Inner Model Goodness of Fit Inner Model struktural pada PLS berupa nilai Q-Square predictive relevance $\left(\mathrm{Q}^{2}\right)$ yang dihitung berdasarkan nilai $\mathrm{R}^{2}$ variabel dependen yaitu kinerja keuangan. Perhitungan $Q^{2}$ dilakukan dengan rumus:

$Q^{2}=1-\left(1-R_{1}^{2}\right)\left(1-R_{2}^{2}\right) \ldots\left(1-R_{p}^{2}\right)$

$R_{1}{ }^{2}, R_{2}{ }^{2} \ldots . . R_{p}{ }^{2}$ adalah $R$-Square variabel endogen dalam model persamaan. Besaran $Q^{2}$ memiliki nilai rentang $0<Q^{2}$

$<1$, dimana semakin mendekati 1 berarti model semakin baik.

c. Pengujian hipotesis: pengaruh langsung dan variabel moderasi

Pengujian hipotesis secara langsung dilakukan terhadap variabel inovasi terhadap kinerja pasar. Keputusan apakah signifikan atau tidak berdasarkan $p$-value lebih kecil dari 5\%. Selanjutnya pengaruh variabel moderasi dilakukan dengan cara memperhatikan signifikansi koefisien masing-masing variabel inovasi terhadap kinerja keuangan, dinamika lingkungan terhadap kinerja keuangan dan interaksi inovasi*dinamika lingkungan terhadap kinerja keuangan. Pemeriksaan jenis variabel moderasi berdasarkan klasifikasi yaitu pure, quasi,homologiser atau predictor moderation. Persamaan struktural berdasarkan model hipotesis adalah:

Kinerja Keuangan $=\mathrm{a}+\beta_{1}$ Inovasi $+\varepsilon$ Kinerja Keuangan $=a+\beta_{1}$ Inovasi + $\beta_{2}$ Dinamika lingkungan + $\beta_{3}$ Inovasi*Dinamika lingkungan $+\varepsilon$

\section{HASIL DAN PEMBAHASAN}

\subsection{Statistik Deskriptif}

Hasil statistik deskriptif terhadap variabel penelitian dapat dilihat pada tabel 4 . Inovasi memiliki nilai maksimum 0,021, nilai minimum 0,000 , nilai rata-rata 0,007 dengan standar deviasi 0,006. Besaran perbedaan terhadap nilai rata-rata cukup kecil dimaknai bahwa data variabel inovasi terdispersi relatif kecil (berada di sekitar rata-rata) atau dapat dikatakan bahwa dengan standar deviasi yang relatif kecil menunjukkan bahwa data tersebut terdistribusi secara homogen. Kondisi ini dimaknai bahwa inovasi yang dilakukan oleh perusahaan sektor telekomunikasi relatif lebih kecil sehingga kemampuan untuk meningkatkan nilai perusahaan relatif menjadi lebih baik. Kemampuan dalam berinteraksi dengan lingkungan industri tampak pada besaran nilai deskriptif dari dinamika lingkungan. Dalam Tabel 4. tampak nilai maksimum 0,009, minimum 1,364 , rata-rata 0,247 dengan standar deviasi 0,256 menunjukkan bahwa variasi data adalah normal atau terdispersi relatif kecil. Hal yang sama tampak pada variabel kinerja keuangan sebagai dependen dalam penelitian ini menunjukkan nilai maksimum 0,000, minimum 0,280, rata-rata 0,076 dengan standar deviasi 0,083. Variasi data mendekati normal karena dispersi standar deviasi relatif lebih besar dengan proporsi perbedaan yang tidak begitu jauh. 
Tabel 4.

Statistik Deskriptif Variabel Penelitian

\begin{tabular}{|l||r||r||r|r|}
\hline \multicolumn{1}{|c|}{ Variabel } & \multicolumn{1}{c|}{ Minimum } & \multicolumn{1}{c|}{ Maksimum } & \multicolumn{1}{c|}{ Rata-rata } & \multicolumn{1}{c|}{ Standar Deviasi } \\
\hline \hline Inovasi & 0,000 & 0,021 & 0,007 & 0,006 \\
\hline \hline Dinamika Lingkungan & 0,009 & 1,364 & 0,247 & 0,256 \\
\hline \hline Kinerja Keuangan & 0,000 & 0,280 & 0,076 & 0,083 \\
\hline
\end{tabular}

Sumber : Data diolah

\subsection{Statistik Inferensial}

\subsubsection{Uji Asumsi Linearitas}

Adapun hasil pengujian kecocokan model dilakukan untuk mengetahui apakah model yang diperoleh telah tepat dalam menggambarkan hubungan antar variabel yang sedang diteliti sehingga dapat dikategorikan kedalam model yang baik. Pendekatan yang digunakan adalah Curve Fit, dengan kaidah keputusan merujuk pada konsep parsimony, yaitu bilamana seluruh model yang digunakan sebagai dasar pengujian adalah signifikan atau tidak signifikan atau fungsi linear signifikan berarti model dikatakan linear. Tabel 5 . tampak bahwa semua bentuk hubungan antar variabel dalam model struktural adalah linear. Dengan demikian asumsi linearitas pada model struktural ini telah terpenuhi.

Tabel 5.

Hasil Pengujian Asumsi Linearitas

\begin{tabular}{|c||c||c|c|c||}
\hline $\begin{array}{c}\text { Variabel } \\
\text { Independen }\end{array}$ & $\begin{array}{c}\text { Variabel } \\
\text { Dependen }\end{array}$ & Hasil Pengujian $(\alpha=0.05)$ & Signifikansi & Keputusan \\
\hline \hline Inovasi $\longrightarrow$ KK & Semua Model Tidak Signifikan & 0,194 & Linear & \\
\hline DL $\longrightarrow$ KK & Semua Model Signifikan & 0,013 & Linear & \\
\hline \hline Keterangan: DL= Dinamika Lingkungan; KK = Kinerja Keuangan & & \\
\hline
\end{tabular}

Sumber : Data diolah

\subsubsection{Evaluasi Model Pengukuran (Outer Model) \\ Pemeriksaan terhadap pengukuran} model adalah dengan interpretasi terhadap outer loading yang diperuntukkan bagi indikator reflektif sehingga diketahui indikator yang paling kuat atau dominan atau dalam penelitian ini menggunakan fit. Penelitian ini menggunakan tiga variabel laten dengan tujuh indikator. Indikator reflektif didasarkan pada outer loading lalu dibandingkan dengan $p$ value pada alpha 5\%. Pemeriksaan ini dilakukan untuk mengindentifikasi indikator apa yang paling penting dan dominan atau fit yang mencerminkan masing-masing variabel laten. Berdasarkan Tabel 6. terlihat bahwa indikator dominan sebagai refleksi dari inovasi adalah perbandingan biaya $R \& D$ terhadap sales, indikator complexity sebagai menjadi indikator dominan dari dinamika lingkungan, sedangkan ROAA dan ROAE sebagai indikator dominan dari variabel kinerja keuangan. Sedangkan indikator R\&D terhadap total aktiva ditemukan tidak signifikans sebagai refleksi dari variabel inovasi, sehingga indikator ini di drop dan tidak digunakan untuk pengujian hipotesis. Dasar penentuan indikator yang di drop sesuai dengan ciri-ciri dari indikator reflektif bahwa antar indikator diasumsikan saling berkorelasi, menghilangkan satu indikator dari model pengukuran tidak akan merubah 
makna dan arti variabel laten (Solimun,

2010: 39).

Tabel 6.

Hasil Pengujian Indikator Variabel Penelitian

\begin{tabular}{||l||l||r||r||r||c||}
\hline Variabel & Indikator & $\begin{array}{c}\text { Outer } \\
\text { Loading }\end{array}$ & t-statistic & p-value & Keputusan \\
\hline \hline Inovasi & R\&D to Sales & 0,936 & 9,758 & 0,000 & Fit \\
\hline \hline & R\&D to TA & 0,098 & 0,338 & 0,738 & Tidak Fit \\
\hline \hline & Dinamika Lingkungan & $-0,539$ & 19,465 & 0,000 & Fit \\
\hline \hline & Complexity & 0,975 & 217,678 & 0,000 & Fit \\
\hline \hline & ROAA & 1,000 & 1012,377 & 0,000 & Fit \\
\hline \hline & ROS & 0,202 & 3,144 & 0,004 & Fit \\
\hline
\end{tabular}

Sumber : Data diolah

\subsubsection{Uji Goodness of Fit Model}

Pemeriksaan terhadap Goodness of Fit berupa nilai predictive-relevance $\left(Q^{2}\right)$ yang dihitung berdasarkan nilai $R^{2}$ masingmasing variabel endogen. Penelitian ini hanya menggunakan satu variabel dependen yaitu kinerja keuangan. Maka nilai $\mathrm{Q}^{2}=1-(1-$ $\left.\mathrm{R}^{2}\right)=0,853$. Artinya model yang digunakan dalam penelitian ini dapat menjelaskan kinerja keuangan sebesar 85,30\% sedangkan sisanya $14,70 \%$ dijelaskan oleh variabel lain yang belum termasuk ke dalam model penelitian.

\subsubsection{Pengujian Hipotesis}

Hasil pengujian hipotesis langsung antara inovasi terhadap kinerja keuangan dan efek moderasi pengaruh inovasi terhadap kinerja keuangan. Hasil analisis data ditampilkan pada Gambar 2. 


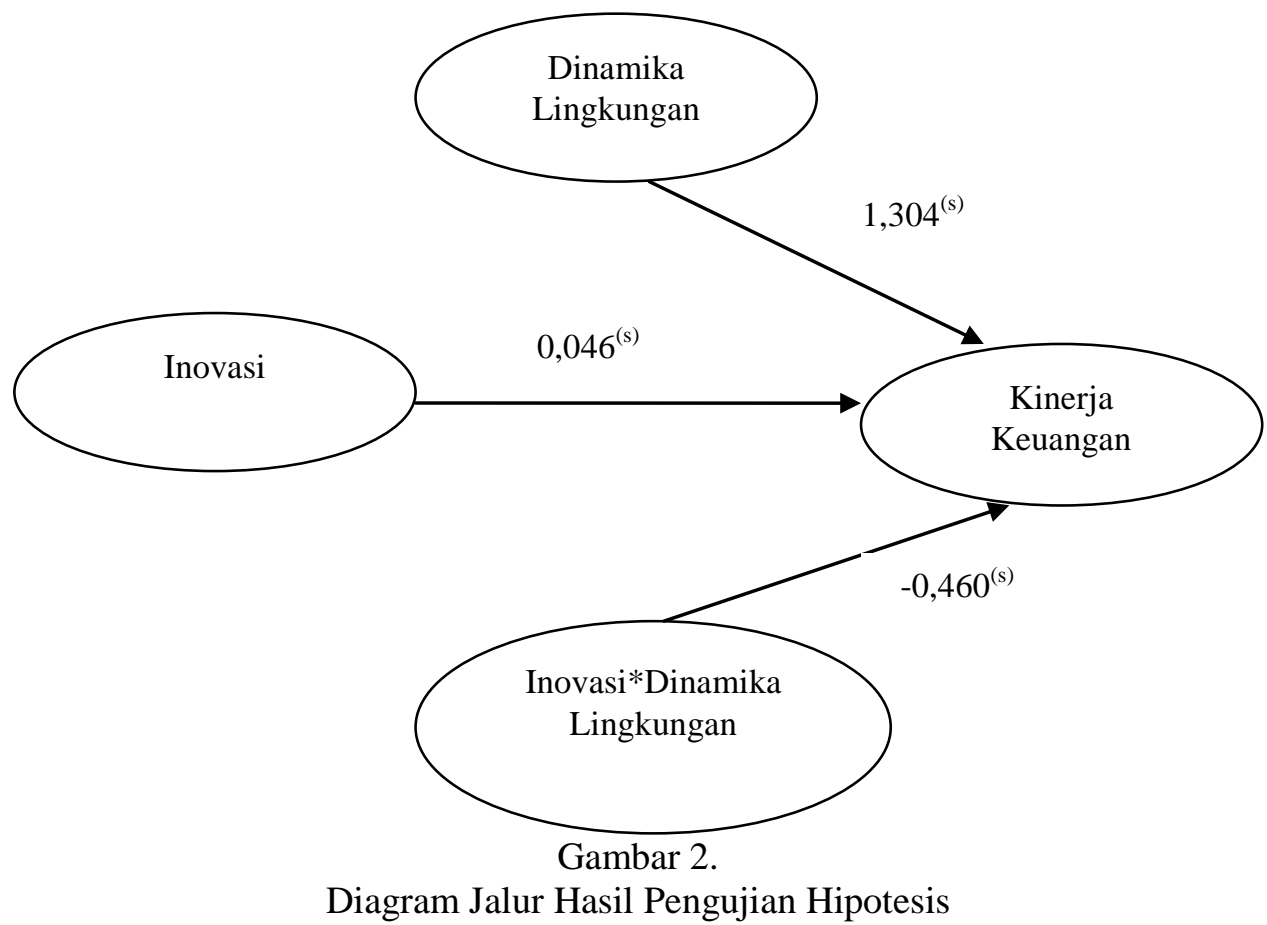

\subsection{Pembahasan Hipotesis}

4.3.1 Pengaruh Inovasi Kinerja Keuangan

Hasil analisis pengaruh inovasi terhadap kinerja keuangan ditemukan signifikan dan positif. Dengan demikian, hipotesis yang menyatakan bahwa inovasi berpengaruh langsung terhadap kinerja keuangan cukup bukti untuk diterima. Hasil ini menunjukkan bahwa semakin tinggi inovasi dapat meningkatkan kinerja keuangan perusahaan sektor telekomunikasi di Indonesia. Merujuk pada analisis model pengukuran menunjukkan bahwa variabel inovasi dicerminkan oleh indikator biaya R\&D terhadap penjualan. Fakta empiris menunjukkan rata-rata inovasi di BEI selama tahun pengamatan adalah 0,007 atau $0,07 \%$ mampu untuk meningkatkan kinerja keuangan sebesar 4,6\%. Hal ini dapat dimaknai bahwa proporsi R\&D dapat meningkatkan penjualan yang akhirnya dapat meningkatkan kinerja keuangan yang tercermin dalam ROAA, ROS dan ROAE.
Berdasarkan nilai penjualan yang mampu diperoleh untuk sampel penelitian adalah tahun 2012 sebesar Rp77.143.000 juta. Perolehan penjualan sektor telekomunikasi berasal dari telepon, seluler, interkoneksi, data internet dan jasa teknologi informatika, jaringan, jasa telekomunikasi lannya. Total penjualan yang terus meningkat setiap tahun mengindikasikan bahwa untuk terus berinovasi adalah tak terbantahkan. Inovasi menjadi sangat penting karena menciptakan daya saing yang pada akhirnya dapat meningkatkan kinerja keuangan. Inovasi di sektor telekomunikasi menjadi sangat penting, mengingat industri pada sektor ini terus melakukan keterbaruan baik di produk, pelayanan maupun programprogram tertentu.

Temuan ini memperkuat teori inovasi dalam perspektif Resources Based View, bahwa perusahaan secara terusmenerus sepanjang waktu untuk mengembangkan inovasi secara internal. Barney (1991:110) dengan jelas 
menguraikan bahwa inovasi adalah bentuk sumberdaya yang penting untuk keunggulan bersaing perusahaan, sebab sumber daya tersebut akan valuable and scarce (sangat bernilai dan langka), bahkan Itami (1987:13) menjelaskan bahwa penggunaan sumber daya yang optimal tidak akan berkurang walaupun digunakan. Pendekatan RBC memfokuskan pada internal resources baik dalam bentuk fisik, financial, human and organizational.

Fakta empiris dalam temuan ini mengindikasikan bahwa sektor telekomunikasi yang tetap berinovasi secara terus-menerus maka akan muncul kebaruan (newness). Pada akhirnya akan menuju kearah keunggulan bersaing dan menjadi unggul dalam sektor industri telekomunikasi. Peningkatan inovasi secara kontinyu, penelitian ini membuktikan bahwa kinerja keuangan tercermin dalam pengembalian rata-rata aktiva, pengembalian rata-rata ekuitas serta peningkatan terhadap penjualan. Koefisien yang positif mencerminkan inovasi yang semakin tinggi akan meningkatkan kinerja keuangan perusahaan.

Hasil penelitian ini memperluas hasil penelitian terdahulu tentang pengaruh signifikan dan positif antara inovasi terhadap kinerja keuangan seperti yang telah dilakukan (Hall, 1993; Srinivasan et al., 2008; Sorescu \& Spanjol, 2008). Perbedaan arah terhadap hasil temuan Sujono (2010) yaitu arah negatif sedangkan penelitian ini positif. Hubungan negatif penelitian Sujono (2010) disebabkan untuk sektor manufaktur adanya kecenderungan moral hazard dalam kegiatan R\&D, sehingga pasar memandang investasi dalam R\&D adalah suatu tindakan yang tidak menguntungkan investor.

\subsubsection{Efek Dinamika Lingkungan sebagai Moderasi Pengaruh}

\section{Inovasi terhadap Kinerja Keuangan}

Hasil pengujian untuk mengetahui interaksi inovasi*dinamika lingkungan dalam memoderasi pengaruh inovasi terhadap kinerja keuangan sektor telekomunikasi di BEI ditemukan hasil yang signifikan dan negatif (Gambar 2.). Hal ini memberikan hasil empiris bahwa interaksi variabel moderasi sebagai interaksi inovasi*dinamika lingkungan secara signifikan memperlemah pengaruh inovasi terhadap kinerja keuangan. Peningkatan kinerja keuangan terjadi saat dinamika lingkungan berpengaruh secara langsung. Hal ini dibuktikan dengan koefisien jalur yang signifikan dan positif (Gambar 2). Pemeriksaan terhadap variabel moderasi dimana pengaruh langsung dan pengaruh moderasi adalah signifikan, maka jenis moderasi adalah quasi moderation atau moderasi semu yang bersifat memperlemah.

Berdasarkan pengukuran model menunjukkan bahwa indikator complexitiy dengan loading factor terbesar yaitu 0,975 (Tabel 6), dengan demikian untuk variabel dinamika lingkungan dalam memoderasi pengaruh inovasi terhadap kinerja keuangan ditentukan oleh variabel interaksi inovasi*dinamika lingkungan. Complexity sebenarnya merupakan cara untuk melihat kemampuan perusahaan dalam mengatasi persaingan industri dan indikator ini diukur dengan cara membandingkan total penjualan masing-masing perusahaan terhadap penjualan industri di sektor telekomunikasi. Tampak secara rata-rata complexity diperoleh 24,7\%, angka ini menunjukkan bahwa perusahaan sektor telekomunikasi di BEI mampu mengatasi persaingan antar perusahaan.

Dinamika lingkungan pada penelitian ini merupakan cerminan dari lingkungan industri yang dapat menjadi sumber kekuatan bagi perusahaan untuk 
memperoleh laba diatas rata-rata (Hitt et al., 2011). Jika perusahaan mampu untuk mengelola lingkungan industri dengan baik, mampu mengatasi persaingan, baik dari pendatang baru maupun pesaing yang lama maka perusahaan mampu untuk meningkatkan profitabilitas. Perusahaan dapat memperoleh informasi yang dibutuhkan untuk mengerti kondisi saat ini serta memprediksi masa yang akan datang sehingga integrasi antar lingkungan harus menjadi perhatian. Sumber informasi diperlukan untuk mengetahui posisi produk tersebut di pasar.

Porter (1980) menjelaskan bahwa untuk merumuskan strategi bersaing penting bagi perusahaan menghubungkan dengan lingkungan. Lingkungan yang dimaksud Porter adalah lingkungan industri dimana perusahaan tersebut bersaing. Kemampuan perusahaan dalam mengatasi lingkungan industri inilah yang dikembangkan Hitt et al. (2011) disebut sebagai mengelola sumbersumber daya perusahaan sebagai input yang terintegrasi sehingga menjadi potensi sumber Sustainable Competitive Advantage (SCA) perusahaan mampu mengungguli pesaingnya sehingga perusahaan dapat mencapai laba diatas rata-rata (superior return).

Penelitian ini mendukung temuan $\mathrm{Li}$ \& Simerly (1998) bahwa moderasi lingkungan terhadap hubungan antara kepemilikan dan kinerja adalah signifikan. Perbedaan arah antara temuan Li \& Simerly (1998) dengan penelitian ini terletak pada pengukuran dari variabel dinamika lingkungan. Variabel interaksi yang digunakan adalah dengan menggunakan dummy variable, sedangkan penelitian ini tidak menggunakan dummy. Hasil penelitian ini menerangkan bahwa lingkungan yang dinamis diperlukan untuk mendukung pencapaian kinerja perusahaan. Perbedaan dengan penelitian ini bahwa dapat disebabkan berbeda dalam pengukuran variabel dinamika lingkungan, perbedaan ini dapat menyebabkan perbedaan dalam temuan penelitian. Temuan penelitian ini berbeda yang dilakukan oleh Keats \& Hitt (1988), Geiger \& Hoffman (1998), Zhao \& Luo (2002), Fauver et al. (2003) yang menemukan adanya hubungan tidak signifikan antara dimensi lingkungan dan kinerja operasi.

\section{KESIMPULAN DAN SARAN}

\subsection{Kesimpulan}

Kesimpulan yang dapat diambil dari penelitian ini adalah sebagai berikut:

a. Inovasi perusahaan sektor telekomunikasi di BEI dicerminkan oleh $R \& D$ to sales mampu untuk meningkatkan kinerja keuangan yang tercermin pada nilai return on average aktiva dan nilai return on average ekuitas. Temuan penelitian ini mengindikasikan bahwa secara rata-rata perusahaan sektor ini mampu untuk meningkatkan kinerja keuangan dengan berinovasi secara terus-menerus sesuai dengan perspektif inovasi berdasarkan resources based view.

b. Interaksi antara inovasi*dinamika lingkungan sebagai moderasi pengaruh inovasi terhadap kinerja keuangan adalah quasi moderation yang bersifat memperlemah. Temuan penelitian ini dimaknai bahwa peningkatan interaksi inovasi*dinamika lingkungan akan menurunkan kinerja keuangan sektor telekomunikasi. Lingkungan industri yang terus harus diperhatikan mengingat sektor ini adalah tingkat persaingan yang cukup ketat dalam memperkenalkan produk, layanan dan program-program kepada masyarakat. 


\subsection{Saran}

Saran-saran yang dapat diberikan dari hasil penelitian ini adalah sebagai berikut:

a. Masih perlu dikembangkan penelitian tentang inovasi baik inovasi proses atau inovasi output. Inovasi proses dapat dilakukan melalui studi kasus untuk mengkaji secara spesifik aktivitas $R \& D$ perusahaan. Inovasi output dapat dikembangkan seperti penelitian ini dengan membahkan variabel lain misalnya kepemilikan perusahaan, karena besarnya biaya $R \& D$ akan dikaitkan dengan pandangan dan kepentingan dari pemegang saham dan manajer perusahaan yang pada akhirnya berdampak terhadap kinerja perusahaan.

b. Perusahaan terus memperhatikan faktor lingkungan turbulance sehingga menjadi fokus untuk mengantisipasi jika terjadi hal-hal yang berdampak pada kondisi internal perusahaan.

c. Penelitian ini hanya dilakukan pada satu sektor saja yaitu telekomunikasi maka penelitian mendatang dapat dikembangkan dengan menggunakan objek pengamatan pada sektor lainnya. Jumlah pengamatan yang relatif kecil menjadi agenda penelitian mendatang untuk menambah jumlah pengamatan. 
Efek Dinamika Lingkungan ... (Yuliani)

\section{DAFTAR PUSTAKA}

Afuah, A. 2003. Innovation Management: Strategies, Implementation and Profit. Oxford University Press, New York.

Aghion, P \& Howitt. 1992. “A Model of Growth through Creative Destruction. Econometrica”. 60: 323351.

Angle, H.L \& Van de Ven, A.H. 2000. "Suggestions for Managing the Innovation Journey". Research on the Management on Innovations: the Minnesota Studies. Oxford University Press. New York.

Balakrishnan, S \& Wernerfelt, B. 1986. "Technical Change, Competition and Vertical Integration". Strategic Management Journal. 7(4): 347-359.

Barney, J. 1991. "Firm Resources and Sustained Competitive Advantage”. Journal of Management., 17(1): 99-120.

Carton, R. B \& Hofer, C. W. 2006. Measuring Organizational Performance: Metrics for Entrepreneurship and Strategic Management Research. Edward Elgar Publishing, Inc. William Pratt House: USA.

Chakravarthy, B.S. 1986.” Measuring Strategic Performance”. Strategic Management Journal. 7(5): 437458.

Damanpour, F \& Wichnevsky, J.D. 2006. "Research Innovation in Organization: Distinguising InnovationGenerating From Innovation-Adopting Organizations”. Journal of Engineering Technology Management. 23: 269-291.

David, F. R. 2003. Strategic Management: Concepts and Cases. $8^{\text {th }}$ Edition, International Edition, Prentice Hall Pearson Education, Inc. Upper Saddle River: New Jersey.

Dess, G. G \& Beard, D. W. 1984. "Dimensions of Organizational Task Environments". Administrative Science Quarterly. 29(1): 52-73.

Drucker, P.F. 1985. “The Discipline of Innovations”. Harvard Business Review. 72-76.

Fauver, L; Joel, F. H, Andy, N. 2003. "Capital Market Development, International Integration, Legal Systems, and the Value of Corporate Diversification: A Cross-Country Analysis”. Journal of Financial and Quantitative Analysis. 38(1): 135-157.

Geiger, S. W \& Hoffman J. J. 1998. "The Impact Of The Regulatory Environment and Corporate Level Diversification on Firm Performance”. Journal of Managerial Issues. 10(4): 439-453. http://www.jstor.org/stable/40604211.

Hall, B. 1993. R\&D Tax Policy During the Eighties: Success of Failure?. Tax Policyand the Economy. 7: 136.

Hambrick, D. C. 1983. “An Empirical Typology of Mature Industrial-Product Environments”. The Academy of Management Journal. 26(2): 213-230.

Helfert, E. A. 2000. Techniques of Financial Management, $5^{\text {th }}$ Edition, Singapore: McGraw-Hill Book Co.

Hitt, M. A.; Ireland, D.R \& Hoskisson, E.D. 2011. Concepts Strategic Management Competitiveness \& Globalization 9e.South-Western Cengage Learning. USA.

. 1997. Manajemen Strategis Menyongsong Era Persaingan dan Globalisasi. Penerbit Erlangga: Jakarta.

Hoskisson, R. E \& Hitt, M. A. 1990. “Antecedents and Performance Outcomes of Diversification: A Review and Critique of Theoritical Perpectives". Journal of Management. 16 (2): 461-509.

Keats \& Hitt. 1988. "A Causal Model of Lingkages Among Environmental Dimension Macro Organizational Characteritic and Performance”. Academy Management Journal. 31 (3): 570-598.

Keputusan Menteri Riset dan Teknologi Republik Indonesia Nomor 193/M/Kp/IV/2010 Tentang Kebijakan Strategis Pembangunan Nasional Ilmu Pengetahuan dan Teknologi Tahun 2010-2014. http:///www.ristek.go.id/indeks. 11 September 2013, akses jam 7:04 WIB.

Li, M \& Simerly, R. L. 1998. "The Moderating Effect of Environmental Dynamism on the Ownership and Performance Relationship”. Strategic Management Journal. 19(2): 169-179.

Mc Arthur, A. W \& Nystrom, P. C. 1991. "Environmental Dynamism, Complexity and Munificence as Moderators of Strategy-Performance Relationship”. Journal of Business Research. 23(4): 349-361. 
Mintzberg, H. 1979. The structuring of Organizations. Prentice-Hal, Englewood Cliffs.

Organization for Economic Co-Operation and Development Statistical Office the European Communities. 2005. Guidline for Collecting and Interpreting Innovation Datam 3 th Ed. OECD Publishing.

Pandya, A. M \& Rao, N. V. 1998. “Diversification and Firm Performance an Empirical Valuation”. Journal of Financial and Strategic Decision, 11 (2):67-81.

Pearce, J. A \& Robinson, R. B. 2011. Strategic Management: Formulation, Implementation and Control. Sixth Edition Irwin. The McGraw-Hill Companies, Inc.

Porter, M. E. 1980. Competitive Strategy Techniques for Analyzing Industries and Competitors. The Free Press. New York.

Roberts, E.B. 1988. “Managing Invention and Innovations”. Research Management. 31: 11-29.

Robinson, K. C \& Mcdougall, P. P. 2001. "Entry Barriers and New Venture Performance: A Comparison of Universal and Contingency Approaches”. Strategic Management Journal. 22(6/7): 659-685.

Robins, J.A \& Wiersema, M. F. 2003. "The Measurement of Corporate Portfolio Strategy: Analysis of the Content Validity of Related Diversification Indexes”. Strategic Management Journal. 24(1): 39-59.

Romer, P. 1990. “Increasing Return and Long Run Growth”. Journal of Political Economics. 94: 10021037.

Scherer, F. 1999. New Perspectives on Economic Growth and Technological Innovation. The Brookings Institution. Washington D.C.

Schumpeter, J. 1934. The Theory of Economic Development, Cambridge Harvard University Press.

Solanas, F. 2008. “The Creative Economiy and The Development Possiblities in Argentina”. Creative dalam Economy as a Development Strategy: A View of Developing Countries. Editor, Reis: Sau Paulo.

Solimun. 2010. Analisis Multivariat Pemodelan Struktural Metode Partial Least Square- PLS. Penerbit CV. Citra: Malang.

Solow, R. 1959. “A Contribution the Theory of Economic Growth”. Quarterly Journal of Economics.70: 6594.

Sorescu, A.B \& Spanjol, J. 2008. "Innovations Effect on Firm Value and Risk: Insight from Consumer Packaged Goods”. Social Science Research Newtwork Paper Collection. http://www.ssrn.com/Abstract--id1265847.

Srinivasan, S; Pauwels, K; Silva-Risso, J \& Hanssen, D.M. 2008. "Product Innovations, Advertising and Stock Returns”. Social Science Research Newtwork Paper Collection. http://www.ssrn.com/Abstract--id1136319.

Sujono. 2010. Determinan Struktur Modal, Inovasi dan Nilai Perusahaan (Studi pada Industri Manufaktur di Bursa Efek Indonesia). Ringkasan Disertasi. Program Doktor Ilmu Manajemen Universitas Brawijaya Malang.

Suta, I. P. G. A. 2006. Kinerja Pasar Perusahaan Publik di Indonesia: Suatu Analisis Reputasi Perusahaan. Disertasi telah diterbitkan. Penerbit Yayasan SAD Satria Bhakti. Jakarta: Indonesia.

Tan, J. 2002. "Impact of Ownership Type on Environment-Strategy Linkage and Performance: Evidence from a Transitional Economy”. Journal of Management Studies. 39(3): 333-354.

Titman, S \& Wessels, R. 1988. “The Determinan of Capital Structure Choice”. Journal of Finance. 43 (1): 1-19.

Weston, J. F \& Copeland, T. E. 1995. Managerial Finance. 9th ed. A. Jaka Wasana MSM \& Kibrandoko MSM. (Penerjemah). Manajemen Keuangan Edisi Kesembilan Jilid 1. Binarupa Aksara. Jakarta Barat. Indonesia.

Wheelen, T. L \& Hunger, J. D. 2000. Strategic Management and Business Policy Eleventh Edition. Pearson International Edition.

Word Economic Forum. 2013. The Global Competitiveness Index 2013-2014 rankings and 2012-2013 comparisons. www.weforum.org. 11 September 2013, akses jam 6:58 WIB.

Yuliani. 2013. Diversifikasi, Investment Opportunity Set, Dinamika Lingkungan dan Nilai Perusahaan (Studi Empiris Sektor Manufaktur di Bursa Efek Indonesia). Disertasi. Program Doktor Ilmu Manajemen Universitas Brawijaya Malang. 
Efek Dinamika Lingkungan ... (Yuliani)

Zhao, H \& Luo, Y. 2002. "Product Diversification, Ownership Structure, and Subsidiary Performance in China's Dynamic Market”. Management International Review. 42(1): 27-48. http://www.jstor.org/stable/40835906. 